\title{
Endogenous antimicrobial factors in the treatment of infectious diseases
}

\author{
PAULINA ŻELECHOWSKA, JUSTYNA AGIER, EWA BRZEZIŃSKA-BEASZCZYK
}

Department of Experimental Immunology, Medical University of Lodz, Lodz, Poland

\begin{abstract}
Nowadays, a number of antibiotic-resistant bacteria strains is increasing. It is a serious clinical problem and poses a threat to the effectiveness of conventional antibiotic therapy. Thus, scientists are constantly seeking new alternatives for treatment of infectious diseases. There are some natural endogenous factors, which possess antimicrobial activities against a large number of microorganisms, including both Gram-positive and Gram-negative bacteria, viruses and fungi. These factors are present in all eukaryotic organisms and constitute an essential element of their immune system. A large number of in vitro and in vivo models have been used to show the activity of antimicrobial factors, and only few studies have been conducted on people. Results indicate that administration of these molecules is therapeutically beneficial. This review summarizes knowledge of selected endogenous antimicrobial agents, such as cathelicidins, defensins, histatins, lysozyme and lactoferrin. We also discuss potential uses of these factors in the treatment of infectious diseases.
\end{abstract}

Key words: lactoferrin (LTF), antimicrobial peptides, histatins, lysozyme, treatment of infectious disease.

(Cent Eur J Immunol 2016; 41 (4): 419-425)

\section{Introduction}

The search for new alternatives to antibiotics becomes unavoidable when we bear in mind the fact that resistance of pathogens towards conventional antibiotics is constantly on the increase. More and more data indicate that there are natural endogenous factors, possessing antimicrobial properties that play an important role in the host defence against pathogens. These factors demonstrate direct activity against microorganisms such as bacteria, viruses, or fungi, and they are able to kill invading microbes. Furthermore, they show a number of immunomodulatory functions that might be involved in the clearance of infection. These factors are found in many cells and tissues and may be produced constitutively or synthesised in response to the presence of pathogens or their products. Hence, the exploration of new solutions with the application of antimicrobial agents for clinical use is still in progress.

Most endogenous factors, characterised by antimicrobial activity, constitute a group of relatively small-sized peptides (antimicrobial peptides - AMPs). Antimicrobial peptides are found in both prokaryotes and eukaryotes, and they are produced by bacteria, invertebrates, and vertebrates. To date, 2706 AMPs have been identified (based on the Antimicrobial Peptide Database). Generally, they consist of 12-50 amino acid residues and they have a positive charge, which is a result of the presence of arginine and lysine residues. For this reason, AMPs are often called cationic peptides. Antimicrobial peptides have an amphipathic structure, enabling them to interact with membranes of a pathogen cell. These peptides are able to destroy the pathogen cell by counteracting with the negatively charged membrane elements of microorganisms. Consequently, it leads to pore formation and membrane permeabilization. Antimicrobial peptides are also capable of penetrating into the pathogen cell. In this way they may inhibit DNA, RNA, and cell wall component synthesis. Nowadays, AMPs are classified into two major and well known groups: cathelicidins and defensins. Apart from cathelicidins and defensins, there are some other important endogenous antimicrobial agents, e.g. histatins, lysozyme, and lactoferrin.

\section{Characteristics of antimicrobial endogenous factors}

Cathelicidins are a group of highly differential peptides, which are found in many mammalian species, including rabbits (18-kDa cationic antimicrobial protein, CAP18), cattle (bactenecin), sheep (cyclic dodecapeptide), mice (mCRAMP), rats (rCRAMP), pigs (protegrins), monkeys (rhLL-37), and humans. All cathelicidins have an $\alpha$-helix linear structure. These peptides show direct antimicrobial activity against a broad spectrum of Gram-positive

Correspondence: Ewa Brzezińska-Błaszczyk, Department of Experimental Immunology, Medical University of Lodz, Pomorska 251, 92-215 Lodz, Poland, e-mail: ewab@csk.umed.lodz.pl

Submitted: 23.05.2016; Accepted: 27.06.2016 
and Gram-negative bacteria, viruses, and fungi. Cathelicidins are synthesised as inactive precursors. The precursor form of cathelicidins consists of highly conserved N-terminal region, catelin domain, and variable $\mathrm{C}$-terminal region. The $\mathrm{C}$-terminal domain is a mature peptide released from the precursor by different serine proteases. So far, the only one human cathelicidin has been identified. It is LL-37 (leucin-leucin 37), which consists of 37 amino acid residues. The gene coding human cathelicidin is located on chromosome 3 . This gene is responsible for cathelicidin synthesis and it involves four exons and three introns. It is characterised by average weight of a base pair, which is about 2000. The precursor of LL-37 is called human CAP18 (hCAP18). The cathelicidin LL-37 is expressed in many cell types, and therefore it is present in different tissues and bodily fluids, such as gastric juices, saliva, plasma, and semen. Cathelicidin LL-37 is constitutively produced by mast cells, NK cells, monocytes, and neutrophils, where it is stored within cytoplasmic granules as an inactive pre-pro-peptide. It has been confirmed that induced expression occurs in enterocytes of the intestine, epithelial cells, and keratinocytes. Recent studies imply that LL-37 expression can be regulated by many endogenous factors, including inflammatory cytokines, growth factors, and active form of vitamin D [1,2].
To date, there is not much data about LL-37 concentration under physiological conditions (Table 1). It is known that in healthy subjects LL-37 concentrations are the following: $30.5 \mathrm{ng} / \mathrm{ml}$ in saliva, $27.2 \mathrm{ng} / \mathrm{ml}$ in plasma, and $0.039 \mathrm{ng} / \mathrm{ml}$ in sputum [3-5]. LL-37 levels in sweat and bronchoalveolar lavage fluid (BAL) of healthy infants are notably higher: $4.47 \mu \mathrm{g} / \mathrm{ml}$ and $4.8 \mu \mathrm{g} / \mathrm{ml}$, respectively [6]. The sputum LL-37 level in asthmatic patients is estimated to be $0.136 \mathrm{ng} / \mathrm{ml}$, whereas the LL-37 concentration in sputum, obtained from cystic fibrosis patients, is $79.6 \mathrm{pg} /$ $\mathrm{ml}$ [5]. The LL-37 concentration in patients with active pulmonary tuberculosis is $49.5 \mathrm{ng} / \mathrm{ml}$ [7]. In systemic sclerosis, patients with interstitial lung disease serum demonstrated lower concentration of LL-37 $(1.36 \mathrm{mg} / \mathrm{ml})$ than healthy subjects $(5.53 \mathrm{ng} / \mathrm{ml})$ [8].

Defensins constitute quite a large and differential group of AMPs, with 3.5-4.5 kDa molecular weight. Defensins contain six cysteine residues, which form three disulphide bridges responsible for stabilisation of the $\beta$-sheet structure of the chain. Defensins are classified into three groups: $\alpha$-defensins, $\beta$-defensins, and $\theta$-defensins. This classification is based on the structure of defensin precursors, the length of the amino acids chain, and the location of disulphide bonds. In humans, defensins are present in many cells, such as neutrophils, thrombocytes,

Table 1. Concentrations of antimicrobial factors

\begin{tabular}{|c|c|c|c|}
\hline \multirow[t]{2}{*}{ Factor } & \multirow[t]{2}{*}{ Material } & \multicolumn{2}{|r|}{ Concentration } \\
\hline & & physiological condition & pathological condition \\
\hline \multirow[t]{2}{*}{ LL-37 } & blood & $27.2 \mathrm{ng} / \mathrm{ml}$ & $\begin{array}{l}\text { systemic sclerosis }-1.36 \mathrm{mg} / \mathrm{ml}[8] \\
\text { tuberculosis }-49.5 \mathrm{ng} / \mathrm{ml}[7]\end{array}$ \\
\hline & sputum & $0.039 \mathrm{ng} / \mathrm{ml}$ & $\begin{array}{l}\text { asthma }-0.136 \mathrm{ng} / \mathrm{ml} \\
\text { chronic obstructive pulmonary disease }-0.753 \mathrm{ng} / \mathrm{ml} \\
\text { cystic fibrosis }-0.79 \mathrm{ng} / \mathrm{ml}[5]\end{array}$ \\
\hline \multirow[t]{3}{*}{$\alpha$-defensin } & blood & $0.91 \mathrm{ng} / \mathrm{ml}$ & $\begin{array}{l}\text { atopic dermatitis }-1.41 \mathrm{ng} / \mathrm{ml}[49] \\
\text { type } 1 \text { diabetes }-28.8 \mathrm{ng} / \mathrm{ml} \\
\text { type } 2 \text { diabetes }-29.8 \mathrm{ng} / \mathrm{ml}[50]\end{array}$ \\
\hline & saliva & $246 \mathrm{pg} / \mathrm{ml}$ & $\begin{array}{c}\text { moderate periodontitis }-628 \mathrm{pg} / \mathrm{ml} \\
\text { severe periodontitis }-784 \mathrm{pg} / \mathrm{ml}[51]\end{array}$ \\
\hline & urine & $15.7 \mathrm{ng} / \mathrm{ml}$ & glomerulonephritis - $21 \mathrm{ng} / \mathrm{ml}$ [17] \\
\hline hBD-2 & sputum & $69.2 \mathrm{pg} / \mathrm{ml}$ & $\begin{array}{l}\text { pneumonia }-178 \mathrm{pg} / \mathrm{ml}[52] \\
\text { diffuse panbronchiolitis - } 264 \mathrm{pg} / \mathrm{ml}[53]\end{array}$ \\
\hline histatin & saliva & $50-425 \mathrm{mg} / \mathrm{ml}$ & $\begin{array}{l}\text { dental caries }-66.8 \mathrm{mg} / \mathrm{ml}[54] \\
\text { HIV }-7.3 \mu \mathrm{g} / \mathrm{ml}[55]\end{array}$ \\
\hline lysozyme & serum & $0.5-2.0 \mu \mathrm{g} / \mathrm{ml}$ & $\begin{array}{c}\text { ankylosing spondylitis }-14.1 \mu \mathrm{g} / \mathrm{ml} \\
\text { Behcet's disease }-14.4 \mu \mathrm{g} / \mathrm{ml} \\
\text { syphilis }-13.98 \mu \mathrm{g} / \mathrm{ml} \\
\text { tuberculosis }-14.99 \mu \mathrm{g} / \mathrm{ml}[56]\end{array}$ \\
\hline \multirow[t]{2}{*}{ lactoferrin } & blood & $176 \mathrm{ng} / \mathrm{ml}$ & $\begin{array}{c}\text { neutropenic sepsis }-20 \mathrm{ng} / \mathrm{ml} \\
\text { non-neutropaenic sepsis }-332 \mathrm{ng} / \mathrm{ml} \text { [57] }\end{array}$ \\
\hline & saliva & $51 \mathrm{ng} / \mathrm{ml}$ & early childhood caries - 37.9 ng/ml [58] \\
\hline
\end{tabular}


monocytes, macrophages, mast cells, NK cells, and epithelial cells. $\alpha$-defensin pre-pro-peptides consist of 90-100 amino acid residues and the precursor containing signal sequence, consisting of 19 amino acid residues, anionic pro-peptide, consisting of five amino acid residues, and the cationic $\mathrm{C}$-terminus domain, which encodes the mature peptide. In humans, $\alpha$-defensins are subdivided into six different types. Four of them are identified in human neutrophils (HNP-1, HNP-2, HNP-3, and HNP-4). Human neutrophil peptides are synthesised as precursors, activated by proteolytic cleavage. During neutrophil differentiation and maturation, HNP 1-4 precursors are excised by neutrophil elastase or proteinase 3 , and then stored in azurophilic granules. $\alpha$-defensin (or cryptidin) expression has also been found in Paneth cells of the intestinal mucosa (HD-5 and HD-6). Modification of HD-5 occurs in the extracellular space, and it is mediated by a trypsin isoform. It has also been confirmed that $\alpha$-defensins are found in urogenital epithelial cells. Well-known human $\beta$-defensins include hBD-1, hBD-2, hBD-3, and hBD-4. hBD-1 is constitutively expressed by keratinocytes and epithelial cells, but it can also be synthesised by monocytes and dendritic cells in response to activation by lipopolysaccharide (LPS) or pro-inflammatory cytokines. The synthesis of defensins hBD-2-4 in keratinocytes, epithelial cells, monocytes, mast cells, and dendritic cells is induced by pro-inflammatory cytokines, such as tumour necrosis factor (TNF) and interleukin (IL)-1 [9]. Cyclic $\theta$-defensins RTD-1 (rhesus theta defensin 1), RTD-2, and RTD-3 were identified during a study of defensin expression in neutrophils and monocytes of the rhesus monkey (Macacca mulata). The $\theta$-defensins are formed by cyclisation of two 76-amino-acid $\alpha$-defensins in post-translational splicing [10].

The physiological serum concentration of hBD-1 in infants is $18 \mu \mathrm{g} / \mathrm{ml}$ [11], whereas the serum concentration of hBD-1 in adults is $8.85 \mathrm{ng} / \mathrm{ml}$. It should be pointed out that hBD-1 serum concentration is higher in cirrhosis (18.26 $\mathrm{ng} / \mathrm{ml}$ ) [12]. The serum hBD-2 level is $0.67 \mathrm{ng} / \mathrm{ml}$ [13]. It is known that in healthy subjects, the sputum hBD-1 concentration is $18.2 \mathrm{ng} / \mathrm{ml}$ [14]. HNP 1-3 concentrations in saliva and BAL are $0.8 \mu \mathrm{g} / \mathrm{ml}$ and $268.3 \mathrm{pg} / \mathrm{ml}$, respectively. The level of HNP-1 in the saliva of patients with oral diseases are found to be significantly higher than the physiological level. The concentration of HNP-1 in the saliva of patients with oral lichen planus, leukoplakia, and glossitis, caused by iron deficiency are $8.3 \mu \mathrm{g} / \mathrm{ml}, 13.2 \mu \mathrm{g} /$ $\mathrm{ml}$, and $11.4 \mu \mathrm{g} / \mathrm{ml}$, respectively $[15,16]$. Interestingly, it has been shown that the concentration of defensins in urine is $15.7 \mathrm{ng} / \mathrm{ml}$, but the concentration of defensins in urine of patients with glomerulonephritis is slightly higher (21 $\mathrm{ng} / \mathrm{ml})$ [17].

It has been confirmed that histidine-rich peptides in primary structure, known as histatins, also possess antibacterial properties. They contain from 7 to 38 amino acid residues in length. Histatins are produced by cells of pa- rotid and submaxillary glands. To date, several peptides belonging to the histatin group have been identified. But the histatin group consists predominantly of the following: histatin 1 (HST1), histatin 3 (HST3), and histatin 5 (HST5). HST1 and HST3 are products of various genes, but HST5 is a proteolytic cleavage product of HST3. What is more, histatins demonstrate antifungal properties. HST5 is the most active histatin against the yeast Candida albicans. Histatins play an important role in the local immune response in the oral cavity. They are found in saliva at a concentration ranging between 50 and $425 \mathrm{mg} / \mathrm{ml}$. Antimicrobial activity is manifested by a reduction of the intracellular ATP by reactive oxygen species, which may induce cell death [18].

Lysozyme is another example of an interesting and widespread AMP, which is one of the better-known natural factors inhibiting bacterial growth. Furthermore, it demonstrates antiviral and antifungal activity. Lysozyme is a hydrolytic enzyme, which is a single peptide chain composed of 129 amino acid residues with a molecular weight of 14.4 $\mathrm{kDa}$. It is found not only in cells such as neutrophils, macrophages, or monocytes, but also in bodily fluids, including serum, saliva, gastric juice, milk, airway mucus secretions, and tears. Human serum lysozyme concentration is about $0.5-2.0 \mu \mathrm{g} / \mathrm{ml}$, whereas its concentration in tears is $2.0-5.0$ $\mu \mathrm{g} / \mathrm{ml}$. Lysozyme mainly destroys Gram-positive bacteria and, to a lesser extent, Gram-negative bacteria. This AMP causes bacterial death by catalytic hydrolysis of their peptidoglycans (PGN). The bond consisting of $\beta$ - $(1,4)$-linked $\mathrm{N}$-acetylglucosamine and $\mathrm{N}$-acetylmuramic acid is broken by lysozyme. Disulphide bonds in spatial lysozyme conformation are responsible for its high thermostability [19].

As it was previously defined, lactoferrin is not classified to AMPs, but is instead one of the glycosylated proteins belonging to the transferrin family, with a molecular weight of $80 \mathrm{kDa}$. Lactoferrin is composed of a single polypeptide chain, which consists of 700 amino acid residues, and it has two homologous lobes: $\mathrm{N}$ and $\mathrm{C}$. Each of them has only one binding site, which may bind one $\mathrm{Fe}^{3+}$ ion. Lactoferrin plays a crucial role in maintaining iron levels in body cells and fluids, especially in milk. Lactoferrin is synthesised by epithelial cells so it is also detected in other secretions of mucosa, including saliva, tears, and semen as well as nasal, bronchial, and vaginal secretions. In milk and colostrum the lactoferrin concentration can reach a value of $7 \mathrm{mg} / \mathrm{ml}$. Currently, it is known that lactoferrin has bacteriostatic activity by blocking iron sources for microorganisms through storing the iron in tissues. By coming into direct interaction with bacterial surfaces, lactoferrin demonstrates its bactericidal function. With regards to Gram-negative bacteria, lactoferrin interacts with bacterial LPS. The destruction of Gram-positive bacteria starts when fragments of the protein possessing a positive charge combine with the bacterial cell membrane [20]. 


\section{Endogenous antimicrobial peptides and their analogues as therapeutic agents}

It is becoming increasingly evident that natural AMPs, as well as their synthetic analogues, can be effective enough to eliminate pathogens. However, it should be emphasised that the available data concerning the therapeutic capabilities of AMPs are limited and ambiguous. A large number of in vitro and in vivo models have been used to characterise the activity of AMPs, and only few studies have been conducted on people. AMPs are still being sought and tested, and currently several clinical trials using these peptides are being conducted or have recently been completed.

In the past few years the significance of cathelicidins in pathogen defence was confirmed in clinical studies. Omiganan pentahydrochloride (MBI 226) is a recently described synthetic analogue of bovine cathelicidin, i.e. indolicidin, a peptide originally purified from the cytoplasmic granules of bovine neutrophils. Extensive in vitro studies conducted on antimicrobial activity of omiganan show that it is active against many Gram-positive species, such as Staphylococcus aureus, Enterococcus faecium, Bacillus sp. and Gram-negative species, e.g. Escherichia coli [21], and fungi, e.g. Candida sp., too [22]. This peptide has just undergone phase III of clinical trials for the prevention of venous catheter-related bloodstream infections. An application of omiganan $1 \%$ gel in an in vivo guinea pig skin colonisation model has revealed that the drug has bactericidal and fungicidal properties and is characterised by important activity against a broad spectrum of pathogens, including $S$. aureus, Staphylococcus epidermidis, and $C$. albicans. Moreover, a significant dose-dependent omiganan activity against $S$. epidermidis was confirmed in an ex vivo pig skin colonisation model [23], and in vitro studies conducted by Dawgul et al. demonstrate destruction of S. epidermidis biofilm and, to a lesser extent, E. coli biofilm, by omiganan [24]. The other synthetic analogue of indolicidin, i.e. MBI 594AN, demonstrates the ability to eradicate Propionibacterium acnes strains. Topical administration of $2.5 \%$ MBI 594AN diminishes the severity of acne lesions, both of inflammatory and non-inflammatory origin [25].

Pexiganan is a synthetic analogue of an African frog-derived peptide - magainin 2. Pexiganan is the first AMP which was introduced on the market as an anti-infective topical drug for the therapy of diabetic foot ulcers. In phase III of clinical trials, involving 835 patients with infected foot diabetic ulcers, application of topical pexiganan contributed to an improvement in $90 \%$ of the patients. Pexiganan demonstrates in vitro antibacterial activity against a lot of Gram-positive and Gram-negative bacteria, isolated from an infected foot, such as Morganella sp., Serratia sp., Enterococcus faecalis, Proteus mirabilis, methicillin-resistant $S$. aureus (MRSA) [26]. Moreover, a dou- ble-blind randomised controlled trial has demonstrated that pexiganan acetate cream may be as effective as oral ofloxacin, a fluoroquinolone antibiotic class, in promoting clinical improvement, pathogen eradication, and wound healing in mildly infected diabetic ulcers [27]. Interestingly, it has been proven that pexiganan is a valuable factor against parasitic protozoan Leishmania sp. An arginine-rich type of pexiganan shows in vitro enhanced action against Leishmania sp. because it proved to be protease-resistant and it induces apoptosis of promastigote forms [28].

Hou et al. [29], in their in vivo studies, showed that LL-37 can be effective in the treatment of MRSA-induced pneumonia. A single administration of LL-37 improved histological images of infected mice lungs. Furthermore, expression levels of pro-inflammatory cytokines in the plasma - IL-6 and TNF - were significantly lower in infected mice treated with LL-37 than in untreated ones. Also, Beaumont et al. [30] conducted in vivo studies that revealed that human cathelicidin may reduce the number of Pseudomonas aeruginosa in BAL of infected mice. In turn, Xia et al. [31] demonstrated that cathelicidin-BF, isolated from the venom of Bungarus fasciatus, is effective in the treatment of Salmonella enterica serovar typhimurium infection. Studies with the use of a mouse model revealed that an application of cathelicidin-BF reduces the spread of bacteria to the spleen and liver, as compared with the untreated control group.

So far, there are some data about defensin therapeutic application. $\alpha$-defensins are shown to be potent particularly against Clostridium difficile strains. To be more precise, HNP-1 and HD-5 inhibit $C$. difficile growth in vitro [32]. The defensin from the bedbug Cimex lectularius is demonstrated to be efficacious against Gram-positive bacteria commonly found on the human skin, such as $S$. aureus, S. epidermidis, Micrococcus luteus, and Corynebacterium renale [33]. Plectasin, the first antimicrobial defensin peptide, isolated from the fungus Pseudoplectania nigrella, has potent in vitro antimicrobial activity against Gram-positive bacteria, including Streptococcus pneumoniae strains resistant to conventional antibiotics. What is more, it is tolerated in high doses and it has appeared to be useful in the treatment of peritonitis and pneumonia in mice [34]. Results of studies on a murine model indicate that the combination of hBD-1 and hBD-2 may be therapeutically effective against salmonellosis [35]. What is interesting, a combination of plant-derived $\beta$-defensins, phBD- 1 , and phBD-2, demonstrates great efficacy with regards to salmonellosis, which was documented in a mouse model [36].

The results of many in vitro and in vivo studies indicate that lactoferrin acts against a lot of Gram-positive bacteria, such as Clostridium sp. and Bacillus subtilis, and Gram-negative bacteria, such as Haemophilus influenzae, Listeria monocytogenes, Helicobacter pylori, Legionella pneumophila, and P. aeruginosa. Moreover, lactoferrin is also known for having antifungal and antiparasitic ac- 
tivities [20]. A clinical trial conducted on a mouse model showed an antimicrobial effect of human lactoferrin, which decreases bacteraemia generated by Streptococcus mutans. Lactoferrin exerts an anti-inflammatory effect as it decreases plasma levels of pro-inflammatory cytokines, interferon (IFN)- $\gamma$, and TNF and C-reactive protein (CRP), too [37].

It should be emphasised that lactoferrin shows antiviral activity, which is demonstrated in the inhibition of poliovirus type 1 , cytomegalovirus, rotavirus viral replication, and blockage of viral access to the host cells. What is important, the proteolytic cleavage of lactoferrin by pepsin leads to production of its derivative - lactoferricin, which is also known as an antiviral factor. In vivo studies on mice showed that this antimicrobial agent is effective in inhibition of Herpes simplex virus type 2 (HSV-2) infection. The in vitro antiviral properties of lactoferrin and lactoferricin have been also documented in the treatment of HSV-2 infection [38]. The prophylactic effect of lactoferrin was also tested. Namely, it has been used as an effective adjuvant for the BCG vaccine. Lactoferrin enhances the efficacy of this vaccine through induction of Th1 immune responses [39].

Remarkably interesting in vivo studies have been conducted by Teenback et al. [40]. They showed a positive effect of lysozyme in the treatment of experimentally generated $P$. aeruginosa lung infection. Treatment with lysozyme decreases levels of cytokine KC (keratinocyte-derived cytokine) and TNF in BAL. It has been confirmed in in vivo studies that lysozome is an antimicrobial agent against $L$. monocytogenes. It appears to reduce levels of inflammatory markers, such as CRP and fibrinogen, and the levels of pro-inflammatory cytokines: IL-6, IL-8, IFN- $\gamma$, and TNF. It should be emphasised that lysozyme exhibits efficient bactericidal activity at the time of bacterial inoculation or five days later [41].

Lysozyme complexes with other components may also be a great alternative for antibiotic therapy against various bacteria. In vitro studies show that such complexes possess antimicrobial activity, which is aimed against some Gram-positive and Gram-negative bacteria. For example, a synthetic complex consists of equine lysozyme and oleic acid (ELOA). It shows a bactericidal effect by accumulating at the cell membrane of $S$. pneumoniae. Such accumulation leads to irreparable depolarisation of membranes and subsequent cell bursting. ELOA is produced from two, easily accessible constituents, so there is a strong likelihood that it will be a novel drug against $S$. pneumoniae infection, which, importantly, will not cause any side-effects [42]. Lysozyme attached to $\mathrm{ZnO}$ nanoparticle is another complex. The synergistic effect of lysozyme and $\mathrm{ZnO}$ conjugate increases antimicrobial activity against $E$. coli and S. aureus [43].

Polysaccharides of Porphyromonas gingivalis are able to induce fibroblast apoptosis. Hence, $P$. gingivalis infec- tion is responsible for tissue destruction in periodontitis. In vitro studies conducted by Imatani et al. [44] indicate that salivary histatin is an important agent that protects against virulence factors of periodontopathic bacteria. Thus, HST5 decreases induction of fibroblast apoptosis caused by $P$. gingivalis. In in vivo studies, Cirioni et al. [45] showed the effectiveness of treatment of $P$. aeruginosa infection with P-113D, a human histatin-derived synthetic peptide. The studies demonstrate the therapeutic efficacy in various rat models of $P$. aeruginosa infection, caecal ligation, and puncture. The studies also confirmed a decrease in endotoxin levels and a considerable reduction of plasma concentration of TNF after a single application of P-113D. Furthermore, shorter peptide derived from HST5 exhibits significant bactericidal activity as well. Homodimerisation of histatin-derived peptides improves in vitro activity against $S$. aureus [46].

Extensive studies were conducted to analyse the antifungal activity of histatin. Genetically engineered HST3 constructs with one, two, three, or four antifungal domain copies show more important, amplified activity against $C$. albicans than normal HST3. These observations indicate a biological advantage and potential effectiveness of HST3 variants in the treatment of cumbersome and hard-to-treat candidiasis [47]. Tati et al. stated that conjugate consisting of polyamine spermidine, linked to the active fragment of HST5 (Hst $5_{4-15}-\mathrm{Spd}$ ), is more effective in vitro than HST5 itself in killing C. albicans and Candida glabrata in both biofilm and planktonic cells. Furthermore, the effect of Hst $5_{4-15}$-Spd for topical application was tested on an immunocompromised mouse model with oropharyngeal candidiasis. The in vivo studies point out that Hst $5_{4-15}-\mathrm{Spd}$ causes considerable reduction of white lesions caused by C. albicans in tongue tissues [48].

\section{Conclusions}

The increasing number of antibiotic-resistant bacteria strains is a serious clinical problem, which poses a threat to the effectiveness of conventional therapy. In most cases this antibiotic resistance is as a result of overuse and improper use of this drug class. It should be emphasised that antibiotics can cause many side effects, such as hepatotoxicity and nephrotoxicity symptoms, as well as allergic reactions. The above problems have encouraged researchers to seek new alternatives that could be used in the therapies of infectious diseases. Undoubtedly, natural antimicrobial factors, including AMPs, can be promising substitutes. Endogenous antimicrobial factors have a lot of potential applications against pathogens, which was confirmed in in vitro and in vivo studies. More and more data indicate that they can also be used in clinical practice. It should be stressed that AMPs are considered safer than antibiotics, because they are natural molecules found in all eukaryotic organisms. Moreover, a lack of bacterial resistance 
to AMPs is also an advantage. Therefore, knowledge of the biological aspects of AMP may contribute to effective treatment of many diseases and also to their prevention. Potential alternative for antibiotics may be human cathelicidin LL-37, $\alpha$-defensins: HNP-1 and HD-5, and $\beta$-defensins: hBD-1 and hBD-2. Histatins, lysozyme, and lactoferrin are also promising agents in treating infectious diseases. Although many studies indicate that administration of AMPs is therapeutically beneficial, further studies on the application potential in humans are required.

This work was supported by the Medical University of Łódź, (Grant No. 503/6-164-01/503-61-001).

The authors declare no conflict of interest.

\section{References}

1. Kościuczuk EM, Lisowski P, Jarczak J, et al. (2012): Cathelicidins: family of antimicrobial peptides. A review. Mol Biol Rep 39: 10957-10970.

2. Kahlenberg JM, Kaplan MJ (2013): Little peptide, big effects: the role of LL-37 in inflammation and autoimmune disease. J Immunol 191: 4895-4901.

3. Davidopoulou S, Diza E, Sakellari D, et al. (2013): Salivary concentration of free LL-37 in edentulism, chronic periodontitis and healthy periodontium. Arch Oral Biol 58: 930-934.

4. Jeng L, Yamshchikov AV, Judd SE, et al. (2009): Alterations in vitamin D status and anti-microbial peptide levels in patients in the intensive care unit with sepsis. J Transl Med 7: 28.

5. Xiao W, Hsu YP, Ishizaka A, et al. (2005): Sputum cathelicidin, urokinase plasminogen activation system components, and cytokines discriminate cystic fibrosis, COPD, and asthma inflammation. Chest 128: 2316-2336.

6. Schaller-Bals S, Schulze A, Bals R (2002): Increased levels of antimicrobial peptides in tracheal aspirates of newborn infants during infection. Am J Respir Crit Care Med 165: 992-995.

7. Yamshchikov AV, Kurbatova EV, Kumari M, et al. (2010): Vitamin D status and antimicrobial peptide cathelicidin (LL37) concentrations in patients with active pulmonary tuberculosis. Am J Clin Nutr 92: 603-611.

8. Hizal M, Bruni C, Romano E, et al. (2015): Decrease of LL37 in systemic sclerosis: a new marker for interstitial lung disease? Clin Rheumatol 34: 795-798.

9. Jarczak J, Kościuczuk EM, Lisowski P, et al. (2013): Defensins: natural component of human innate immunity. Hum Immunol 74: 1069-1079.

10. Conibear AC, Craik DJ (2014): The chemistry and biology of theta defensins. Angew Chem Int Ed Engl 53: 10612-10623.

11. Zhang T, Liao JY (2012): Serum levels of human $\beta$-defensins 1 and immunoglobulins $\mathrm{A}, \mathrm{G}$ and $\mathrm{M}$ in infants with recurrent pneumonia. Zhongguo Dang Dai Er Ke Za Zhi 14: 431-433.

12. Kaltsa G, Bamias G, Siakavellas SI, et al. (2016): Systemic levels of human $\beta$-defensin 1 are elevated in patients with cirrhosis. Ann Gastroenterol 29: 63-70.

13. Gedik AH, Cakir E, Gokdemir Y, et al. (2015): Cathelicidin (LL-37) and human 32 -defensin levels of children with post-infectious bronchiolitis obliterans. Clin Respir J doi: 10.1111/crj.12331.
14. Baines KJ, Wright TK, Simpson JL, et al. (2015): Airway $\beta$-defensin-1 protein is elevated in COPD and severe asthma. Mediators Inflamm 407271.

15. Mizukawa N, Sugiyama K, Ueno T, et al. (1999): Defensin-1, an antimicrobial peptide present in the saliva of patients with oral diseases. Oral Dis 5: 139-142.

16. Tiriveedhi V, Banan B, Deepti S, et al. (2014): Role of defensins in the pathogenesis of chronic lung allograft rejection. Hum Immunol 75: 370-377.

17. Tikhonov I, Rebenok A, Chyzh A (1997): A study of interleukin- 8 and defensins in urine and plasma of patients with pyelonephritis and glomerulonephritis. Nephrol Dial Transplant 12: 2557-2561.

18. Kavanagh K, Dowd S (2004): Histatins: antimicrobial peptides with therapeutic potential. J Pharm Pharmacol 56: 285289.

19. Gajda E, Bugla-Płoskońska G (2014): Lysozyme - occurrence in nature, biological properties and possible applications. Postepy Hig Med Dosw 68: 1501-1515.

20. González-Chávez SA, Arévalo-Gallegos S, Rascón-Cruz Q (2009): Lactoferrin: structure, function and applications. Int J Antimicrob Agents 33: 301.e301-301.e308.

21. Sader HS, Fedler KA, Rennie RP, Stevens S, et al. (2004): Omiganan pentahydrochloride (MBI 226), a topical 12-amino-acid cationic peptide: spectrum of antimicrobial activity and measurements of bactericidal activity. Antimicrob Agents Chemother 48: 3112-3118.

22. Fritsche TR, Rhomberg PR, Sader HS, Jones RN (2008): Antimicrobial activity of omiganan pentahydrochloride against contemporary fungal pathogens responsible for catheter-associated infections. Antimicrob Agents Chemother 52: 11871189.

23. Rubinchik E, Dugourd D, Algara T, et al. (2009): Antimicrobial and antifungal activities of a novel cationic antimicrobial peptide, omiganan, in experimental skin colonisation models. Int J Antimicrob Agents 34: 457-461.

24. Dawgul M, Maciejewska M, Jaskiewicz M, et al. (2014): Antimicorbial peptides as potential tool to fight bacterial biofilm. Acta Pol Pharm 71: 39-47.

25. Gordon YJ, Romanowski EG, McDermott AM (2005): A review of antimicrobial peptides and their therapeutic potential as anti-infective drugs. Curr Eye Res 30: 505-515.

26. Ge Y, MacDonald D, Henry MM, et al. (1999): In vitro susceptibility to pexiganan of bacteria isolated from infected diabetic foot ulcers. Diagn Microbiol Infect Dis 35: 45-53.

27. Lipsky BA, Holroyd KJ, Zasloff M (2008): Topical versus systemic antimicrobial therapy for treating mildly infected diabetic foot ulcers: a randomized, controlled, double-blinded, multicenter trial of pexiganan cream. Clin Infect Dis 47: 1537-1545.

28. Kulkarni MM, Karafova A, Kamysz W, McGwire BS (2014): Design of protease-resistant pexiganan enhances antileishmanial activity. Parasitol Res 113: 1971-1976.

29. Hou M, Zhang N, Yang J, et al. (2013): Antimicrobial peptide LL-37 and IDR-1 ameliorate MRSA pneumonia in vivo. Cell Physiol Biochem 32: 614-623.

30. Beaumont PE, McHugh B, Findlay EG, et al. (2014): Cathelicidin host defence peptide augments clearance of pulmonary Pseudomonas aeruginosa infection by its influence on neutrophil function in vivo. PLoS One 9: e99029.

31. Xia X, Zhang L, Wang Y (2015): The antimicrobial peptide cathelicidin-BF could be a potential therapeutic for Salmonella typhimurium infection. Microbiol Res 171: 45-51. 
32. Furci L, Baldan R, Bianchini V, et al. (2015): New role for human $\alpha$-defensin 5 in the fight against hypervirulent Clostridium difficile strains. Infect Immun 83: 986-995.

33. Kaushal A, Gupta K, van Hoek ML (2016): Characterization of Cimex lectularius (bedbug) defensin peptide and its antimicrobial activity against human skin microflora. Biochem Biophys Res Commun 470: 955-960.

34. Mygind PH, Fischer RL, Schnorr KM, et al. (2005): Plectasin is a peptide antibiotic with therapeutic potential from a saprophytic fungus. Nature 437: 975-980.

35. Maiti S, Patro S, Purohit S, et al. (2014): Effective control of Salmonella infections by employing combinations of recombinant antimicrobial human $\beta$-defensins hBD-1 and hBD-2. Antimicrob Agents Chemother 58: 6896-6903.

36. Patro S, Maiti S, Panda SK, Dey N (2015): Utilization of plant-derived recombinant human $\beta$-defensins (hBD- 1 and hBD-2) for averting salmonellosis. Transgenic Res 24: 353364.

37. Velusamy SK, Fine DH, Velliyagounder K (2014): Prophylactic effect of human lactoferrin against Streptococcus mutans bacteremia in lactoferrin knockout mice. Microbes Infect 16: $762-767$.

38. Shestakov, A Jenssen H, Nordström I, Eriksson K (2012): Lactoferricin but not lactoferrin inhibit Herpes simplex virus type 2 infection in mice. Antiviral Res 93: 340-345.

39. Hwang SA, Arora R, Kruzel ML, Actor JK (2009): Lactoferrin enhances efficacy of the BCG vaccine: comparison between two inbred mice strains (C57BL/6 and BALB/c). Tuberculosis (Edinb) 89 Suppl 1: S49-S54.

40. Teneback CC, Scanlon TC, Wargo MJ, et al. (2013): Bioengineered lysozyme reduces bacterial burden and inflammation in a murine model of mucoid Pseudomonas aeruginosa lung infection. Antimicrob Agents Chemother 57: 5559-5564.

41. Palumbo D, Iannaccone M, Porta A, Capparelli R (2010): Experimental antibacterial therapy with puroindolines, lactoferrin and lysozyme in Listeria monocytogenes-infected mice. Microbes Infect 12: 538-545.

42. Clementi EA, Wilhelm KR, Schleucher J, et al. (2013): A complex of equine lysozyme and oleic acid with bactericidal activity against Streptococcus pneumoniae. PLoS One 8: e80649.

43. Tripathy N, Ahmad R, Bang SH, et al. (2014): Tailored lysozyme-ZnO nanoparticle conjugates as nanoantibiotics. Chem Commun (Camb) 50: 9298-9301.

44. Imatani T, Kato T, Okuda K, Yamashita Y (2004): Histatin 5 inhibits apoptosis in human gingival fibroblasts induced by Porphyromonas gingivalis cell-surface polysaccharide. Eur J Med Res 9: 528-532.

45. Cirioni O, Giacometti A, Ghiselli R, et al. (2004): Potential therapeutic role of histatin derivative P-113D in experimental rat models of Pseudomonas aeruginosa sepsis. J Infect Dis 190: 356-364.

46. Welling MM, Brouwer CPJM, van't Hof W, et al. (2007): Histatin-derived monomeric and dimeric synthetic peptides show strong bactericidal activity towards multidrug-resistant Staphylococcus aureus in vivo. Antimicrob Agents Chemother 51: 3416-3419.

47. Oppenheim FG, Helmerhorst EJ, Lendenmann U, Offner GD (2012): Anti-candidal activity of genetically engineered histatin variants with multiple functional domains. PLoS One 7: e51479.

48. Tati S, Li R, Puri S, et al. (2014): Histatin 5-spermidine conjugates have enhanced fungicidal activity and efficacy as a topical therapeutic for oral candidiasis. Antimicrob Agents Chemother 58: 756-766.

49. Tsybikov NN, Petrisheva IV, Fefelova EV, et al. (2016): Plasma $\alpha$-defensins are elevated during exacerbation of atopic dermatitis. Clin Exp Dermatol 41: 253-259.

50. Németh BC, Várkonyi T, Somogyvári F, et al. (2014): Relevance of $\alpha$-defensins (HNP1-3) and defensin $\beta-1$ in diabetes. World J Gastroenterol 20: 9128-9137.

51. Hofman J, Szkaradkiewicz AK, Karpiński TM (2008): Evaluation of defensin (HNP 1-3) presence in saliva and serum of patients with chronic periodontitis. Czas Stomatol 61: 881885.

52. Harimurti K, Djauzi S, Witarto AB, Dewiasty E (2011): Human $\beta$-defensin 2 concentration of respiratory tract mucosa in elderly patients with pneumonia and its associated factors. Acta Med Indones-Indones J Intern Med 43: 218-223.

53. Hiratsuka T, Mukae H, Iiboshi H, et al. (2003): Increased concentrations of human $\beta$-defensins in plasma and bronchoalveolar lavage fluid of patients with diffuse panbronchiolitis. Thorax 58: 425-430.

54. Gornowicz A, Tokajuk G, Bielawska A, et al. (2014): The assessment of $\operatorname{sgA}$, histatin-5, and lactoperoxidase levels in saliva of adolescents with dental caries. Med Sci Monit 20: 1095-1100.

55. Torres SR, Garzino-Demo A, Meiller TF, et al. (2008): Salivary histatin-5 and oral fungal colonisation in HIV+ individuals. Mycoses 52: 11-15.

56. Sahin O, Ziaei A, Karaismailoğlu E, Taheri N (2016): The serum angiotensin converting enzyme and lysozyme levels in patients with ocular involvement of autoimmune and infectious diseases. BMC Ophthalmol 16: 19.

57. Thomas NJ, Carcillo JA, Doughty LA, et al. (2002): Plasma concentrations of defensins and lactoferrin in children with severe sepsis. Pediatr Infect Dis J 21: 34-38.

58. Moslemi M, Sattari M, Kooshki F, et al. (2015): Relationship of salivary lactoferrin and lysozyme concentrations with early childhood caries. J Dent Res Dent Clin Dent Prospects 9: 109-114. 